\title{
LEGAL ANTHROPOLOGY AND THE CONSTRUCTION OF COMPLEX LIABILITIES
}

There is something common among international trials that have involved the use of command responsibility, in that the boundaries of fault in some cases were not at all clear. Here, I distinguish between material fault and liability. Material Fault is impossible in the absence of a pre-existing criminal conduct, which in turn gives rise to liability. This liability may further be distinguished twofold: firstly, in terms of satisfying the mental and factual elements of the offence in question (which may be termed legal fault), and; secondly, in terms of categorising the perpetrator's overall participation in the crime (ie as principal, accessory, co-perpetrator or other). Thus, it follows that fault is circumscribed and dependent on the particular forms of liability pertinent to each offence. By way of illustration, liability for unlawful homicide lies with the direct perpetrator, as well as possible accessories. Quite clearly, fault and liability are ascribed to the same actors. This pattern is pretty much consistent in domestic criminal laws, no doubt because domestic crimes in their majority do not involve complex organisations and multiple victims. In international law, the aforementioned fault-liability paradigm has been severed not only because of the obvious complexity underlying international crimes such as genocide and crimes against humanity, but more importantly because it is recognised that the concept of legal and material fault is incapable of fully encompassing the complexities of justice lato sensu. The liability associated with the responsibility of persons in authority and effective control over others seems at first glance to satisfy the dictates of justice. However, as the authors writing on command responsibility in this volume have rightly identified, as well as those writing before them, when one departs from the fault-liability paradigm, one has to justify this expansion of fault. If this is not done convincingly it will lack legitimacy and will therefore undo the very justice it was originally set up to serve. ${ }^{1}$

What is also a common thread behind international criminal trials since the ICTY, and which has a direct bearing on command responsibility, is the fact that the donors, through the collective facade of "international community", expect convictions rather than justice more generally. This is exemplified by numerous accounts, but I will simply state a few. Of particular importance are: a) the constructions of complex liabilities, such as joint criminal enterprise (JCE) and command responsibility in the absence of other liabilities that facilitate conviction; b) the attraction of donors through the semantics of convictions and the subsequent success of the various prosecutors on this basis, as well as; c) the absence of any meaningful dialogue with the victimised communities in order to assess their needs and desires with respect to transitional justice and development.

Ethnographic studies on the SCSL's outreach program in the heartlands of Sierra Leone, for example, demonstrate that the people were simply informed of the international community's decision and effort to establish the Special Court, but were not meaningfully consulted on any alternatives or asked to express their own desires and aspirations. Ultimately, it seems that the majority of the local population were not simply highly suspicious of the Special Court but more importantly their primary concerns centred around the fulfilment of fundamental human needs and development rather than meting out

\footnotetext{
${ }^{1}$ This lack of legitimacy has been a constant criticism of JCE. See ME Badar, Just Convict Everyone! Joint Perpetration: From Tadic to Stakic and Back Again (2006) 6 International Criminal Law Review 293.
} 
expensive justice to a handful of individuals. ${ }^{2}$ Hence, it is not clear whether the formulation of complex liabilities beyond the fault-liability paradigm is the product of donor expectations for convictions or the direct result of justice gaps identified by the judges of international tribunals that are freed from the procedural and constitutional limitations inherent in domestic systems. The truth must necessarily lie somewhere in the middle.

The current status of command responsibility under international law is well settled, at least in most respects. ${ }^{3}$ It would probably be more accurate to say that there is widespread agreement as regards its boundaries, because there is still fierce debate as to how we should approach knowledge and effective control, among others. What I propose to do in the remainder of this comment is to assess the evolution and difficulties in applying the doctrine, as elaborated thus far in scholarly opinion and the jurisprudence of courts and tribunals, from the point of view of the anthropological realities of Africa and Sierra Leone.

\section{Anthropology as a Tool for Assessing Complex Liabilities}

Anthropology and law seem at first glance to have nothing in common. The first seeks to elucidate collective human behaviour and understand its cultural underpinnings whereas the second is concerned with rules and order. It is evident that since rules and order are not produced in a void but rather with a view to regulating human relations, it follows that law is a necessary component of culture in the same manner as work, leisure, art, religion and others. ${ }^{4}$ Law need not necessarily be formal, as is the case with legislation that is promulgated under strict constitutional procedures, but it may just as well be informal without the sanction of government. This informal law does not only exist in past and present rural societies in the heartlands of Africa and Asia, but also in the very midst of industrialised western societies. The so-called lex mercatoria and the pursuit of self-regulation by particular industries, as is indeed the very concept of contract and party autonomy thereto, ${ }^{5}$ is evidence of man's desire to regulate in certain cases human interaction by means of informal, but no less binding, prescriptions. Besides regulating human relations, both formal and informal law, particularly the latter, provides evidence of social relations, status and social interaction within a given community. By way of illustration, the village chief is typically the judge and the recognised authority in the interpretation of customary law and as such is regarded as a revered figure. Equally, the male warriors of the tribe, whose authority to hunt recognised as a customary entitlement, may enjoy first rights to the tribe's game. Social status and the existence of complex roles and rules are also evident in the internal sphere of criminal gangs operating in industrialised settings. ${ }^{6}$ In Islamic law, too, the social from the legal is inseparable in countries strictly adhering to classical Shariah. For example, the inferior status

\footnotetext{
${ }^{2}$ G Anders, Juridification, Transitional Justice and Reaching out to the Public in Sierra Leone, in J Eckert, B Donahoe, C Strümpell, ZO Biner (eds), Law against the State: Ethnographic Forays into Law's Transformations (Cambridge UP, 2012) 94, at 100, 108.

${ }^{3}$ See G Mettraux, The Law of Command Responsibility (Oxford UP, 2009), who paints an accurate and holistic picture of the boundaries and controversies surrounding the concept.

${ }^{4}$ For a general overview, see JM Conley, WM O'Barr, Legal Anthropology comes Home: A Brief History of the Ethnographic Study of Law (1993) 27 Loyola of Los Angeles Law Review 41.

${ }^{5}$ According to Teubner, the ultimate validation of lex mercatoria rests on the fact that not all legal orders are created by the nation State and accordingly that private orders of regulation can create law. G Teubner,Global Bukowina: Legal Pluralism in the World Society, in G Teubner (ed) Global Law without a State (Dartmouth, 1997) 15.

${ }^{6}$ See JD Vigil, Urban Violence and Street Gangs (2003) 32 Annual Review of Anthropology 225; D Lamm Weisel, Contemporary Gangs: An Organisational Analysis (LBF Scholarly Publishing, 2002).
} 
ascribed to women in terms of entitlements (eg the right to be elected, weight of testimony etc) also determines their social status.

At a very basic level and in relation to our study of command responsibility, anthropology can assist us to ascertain those elusive de facto indicia that are necessary for constructing authority, power and ultimately effective control. It also allows us to understand whether the "subordinates" that committed the crimes were under sufficient compulsion or control by their superior, such that justifies the latter's conviction despite the absence of direct fault. Before we go on, however, it is important to make a significant observation that relates to semantics. If anthropology is viewed as a method by which to draw conclusions pertinent to the fault-liability paradigm or complex liabilities, then this method requires an appropriate language in order to communicate concepts and ideas into the sphere of law. ${ }^{7}$ Communication is crucial not only because certain words are not translatable from one language to another, but also because wholesale concepts and ideas themselves are alien from one culture to another. ${ }^{8}$ A very poignant example is necessary in order to better illustrate the point. In the case against Charles Taylor, a prosecution witnesses named "ZigZag" Marzah was quite clearly unfamiliar with the Western idiom of remorse and conscience. ${ }^{9}$ He also claimed that he was involved in cannibalism of enemy corpses, arguing that this was something expected of all warriors battling on the side of Charles Taylor. ${ }^{10}$ Whether or not this statement is true, it certainly stirs a wealth of emotions in the Western psyche and reinforces myths and stereotypes associated with primitive Africa. In fact, anthropological research reveals that cannibalism was historically unknown in African societies. Anders recalls the Human Leopards case investigated by a Special Commission Court set up by British colonial authorities in early twentieth century Sierra Leone. There, and without any corroborating forensic evidence, the court was convinced that members of a secret society dressing up in leopard skins went about ritual cannibalism. The basic story was described by insider witnesses whose communication with their colonisers must have been agonising through language that was fraught with significant misunderstanding and symbolism and which was moreover read through two very different socio-cultural perspectives. Anders accurately captures this as follows:

In Sierra Leone and Liberia, as in many parts of Africa, social relationships and personal development are framed in a rich language of eating and consumption. Initiation into secret societies such as the poro is also expressed in an idiom of being eaten or devoured by the bush spirits in order to be reborn as a full member of the community. ... The political sphere, in particular, is conceptualised as a potentially dangerous terrain where powerful people "eat" each other in order to grow "big". This has been famously coined by Bayart as the politics of the belly, who describes the consumption of the State's resources by politicians and bureaucrats. In Sierra Leone, corrupt politicians are referred to as bobor bele - literally, guys with a belly eating the State's resources. Therefore, the frequent cannibalism accusations in West Africa must not always be read literally. They should rather be interpreted in terms of a highly symbolic political language and critique of existing injustices [as is the case with Sierra Leone]. ${ }^{11}$

\footnotetext{
${ }^{7}$ See E Mertz, Language, Law and Social Meanings: Linguistic/Anthropological Contributions to the Study of Law (1992) 26 Law \& Society Review 413.

${ }^{8}$ See M Van Hoecke, Law as Communication, (Hart, 2002), in which the author's central thesis is that all legal relations are to be understood in terms of dialogue, conversation and communicative processes, rather than as traditional command-obedience structures. Legal anthropologists such a Bohannan argued that Western legal terms and categories should not be employed to study the organisation and order of non-Western societies. He believed that such a methodology prevented a comprehensive understanding of other cultures and argued in favour of using native legal terms whose meaning would become evident within an ethnographic context. $\mathrm{P}$ Bohannan, Justice and Judgment among the Tiv (Oxford UP, 1957).

${ }^{9}$ G Anders, Testifying about Uncivilised Events: Problematic Representations of Africa in the Trial against Charles Taylor (2011) 24 Leiden Journal of International Law 937, at 944-45.

${ }^{10}$ Ibid, at $948-49$.

${ }^{11}$ Ibid, at 956.
} 
To a Western audience it seems implausible that anyone can genuinely confuse symbolism from reality, or to put it bluntly, to confuse actual cannibalism from its metaphors. How can you say one thing and, without lying, actually mean something completely different? How is it that symbolism can be so easily transformed into action? This is not the time or place to expand fully on these issues and I am not sure I have the requisite knowledge to do so, and thus I will simply make reference to two case studies from the recent past. A significant part of the Rwandan genocide was predicated on a myth or symbolism reiterated and spread by the Hutu that the Tutsi were cockroaches and inferior beings. Whereas no Hutu would typically act on this myth unilaterally, it was the seed for future events when animosity was stirred through artificial means and channels and in which case an illiterate and highly polarised populace was unable to separate myth from reality. Anthropological research on the Rwandan genocide tends to show that one of the principal cultural metaphors in Rwanda, the "flow", may shed some light on some of the methods for killing and torturing used by the Hutu. Flow in general represents something healthy, as is the case with our blood stream or the transformation of food into faeces and insemination into childbirth. Blockage of flow is associated with disease and death. The impalement of victims from the anus to the mouth as well as mass killings at check points, in addition to other motives, symbolises the end of flow. ${ }^{12}$ To a western audience it may to some degree explain certain acts of sheer cruelty (although certainly not fully), as well as placate genocidal patterns amounting to systematic.

The second example is very similar, despite the fact that it took place more than fifty years earlier and fuelled the psyche of a much more literate and "civilised" population. I am referring to Nazi propaganda well prior to the commencement of World War II in 1939 through a process of dehumanizing its enemies, such as Slavs, communists and Jews. The rest of the story is well known.

In the context of the ICTR's investigation, legal anthropology played a significant part in the reconstruction of liability for genocide. It will be recalled that in its first case, that of Jean Paul Akayesu, the Tribunal was reluctant to apply the exact terms of Article II of the Genocide Convention which required that the crime could only be committed against members of another ethnic, national, religious or racial groups. Forensic evidence demonstrated that the Hutu and the Tutsi were not ethnically or racially distinct; quite the opposite. Their respective designations had been engineered by their Belgian colonisers and these had subsequently matured into distinctions of class or social status. The Tribunal therefore turned to legal anthropology in order to construct a more objective theory of victimhood for the purposes of the Genocide Convention. It held that beyond external characteristics such as race and ethnic origin, membership of a group may also come about by the personal belief of a group's members as to their distinctiveness. ${ }^{13}$ This personal selfdistinction and self-categorisation is sanctioned only if it is validated by anthropological evidence; that is, if the group members have actually distinguished themselves and in addition other groups perceive them as being distinct. For the purposes of command responsibility, the conclusion is that such groups cannot, without evidence to the contrary, be presumed to be under the de facto control of non-group members.

12 CC Taylor, The Cultural Face of Terror in the Rwandan Genocide, in AL Hinton (ed), Annihilating Difference: The Anthropology of Genocide (University of California Press, 2002) 137-78.

${ }^{13}$ ICTR Prosecutor v Akayesu, Trial Chamber Judgment (2 Sep 1998), para 702. In ICC Prosecutor v Al-Bashir, Decision on the Prosecution's Application for a Warrant of Arrest against Omar Al-Bashir (4 Mar 2009) [AlBashir Warrant Decision], para 137, an ICC Pre-Trial Chamber claimed that three Sudanese tribal groups living in the same area, namely the Fur, the Masalit and the Zaghawa constituted distinct ethnic groups because each possesses its own language, tribal customs and traditional links to its lands. Without realising it, the Pre-Trial Chamber made an anthropological observation with legal significance. 


\section{Elusive Effective Control}

One of the issues identified in the chapters dealing with command responsibility is the degree to which one may assume effective control in respect of jungle-based armies and militias. This is by no means a new theme, given that it has troubled law-makers and courts since command responsibility was first punctuated on the legal map with the Yamashita case. ${ }^{14}$ There, it was controversially held that Yamashita retained effective control over Japanese troops that went on the rampage against civilians in Manila, even though he had split the Japanese forces on the Philippines in four distinct groups with all communication between them having been severed by their adversaries. The tribunal maintained that the atrocities were so widespread that Yamashita must have known about them and could have prevented them, despite the argument of the accused that he had given strict instructions to the Manilabased commander to evacuate the island and return to Japan. Clearly, in the absence of any direct orders the tribunal could not have constructed Yamashita's command liability had it not arbitrarily assumed that he enjoyed effective control of all Japanese forces on the island.

Whatever the actual facts on the ground, a retrospective examination of effective control would no doubt be illumined by reference to anthropological data. Again, it is not my intention to go into any significant detail, but given that the case hung on whether Yamashita's subordinates had in fact disobeyed his orders to evacuate and to avoid harming civilians, it is worth investigating Japanese military culture at the time. With the adoption of Shinto as the country's official State religion in 1890 an emperor cult was established whereby the emperor's divinity was based on his descent from the Goddess Amaterasu. This meant that the emperor's commands, and by implication those of his representatives, were to be obeyed without objection. This unswerving loyalty to the emperor as the basis of the Japanese State (known as kokutai, which may be translated manifold, particularly "sovereign" or "national essence") had earlier been institutionalised by the introduction of universal conscription which resulted in the indoctrination of the country's youth and which continued through subsequent generations. ${ }^{15}$ This cultural dimension, coupled undoubtedly with fear and other elements, accounts for the acceptance of brutality within the ranks of the Japanese army and its members' loyalty-to-the-death. As a result, it would have been characteristically untypical and out of all logic for the forces under Yamashita's de jure command to disobey their commander's direct orders. By logical implication, no distinction can be made between de jure and de facto command in respect of Japanese military organisation during World War II because even if separated from their commanders, units and sub-units therefore, would always religiously adhere to their superiors' original orders unless of course there were no other available orders. This observation also suggests that in this particular socio-military context the absence of material capacity to prevent or punish is irrelevant in establishing de facto or de jure command because the conduct of subordinates is uniform irrespective of the person under command.

In the Rwanda conflict, de facto command and control became a central issue because, unlike the military-styled paramilitary groups on the territory of the former Yugoslavia, a significant amount of authority was exercised on the basis of traditional socioeconomic structures. Rwandan society, like most of Africa, is tribal and class-based, with

\footnotetext{
${ }^{14}$ Trial of General Tomoyuki Yamashita, 4 Law Reports of Trials of War Criminals 1.

${ }^{15}$ In fact, kokutai was introduced as a fundamental building block in Article 4 of Japan's 1890 Constitution, also known as the Meiji Constitution, on account of the Tenno dynasty which assumed power through the 1868 Meiji restoration, remaining in power until 1945. See GM Beckmann, The Making of the Meiji Constitution: The Oligarchs and the Constitutional Development of Japan, 1868-1891 (University of Kansas Press, 1957).
} 
authority and privileges typically belonging to the elite in each tribe or clan. ${ }^{16}$ As a result, authority and wealth go hand-in-hand, with the elite also being the richest and better educated among the tribe. Until the creation of the ICTR the construction of command responsibility had been applied to regular armies and, at worst, to tightly-structured paramilitary units, which however resembled regular armies principally because they were formed and run by ex-military personnel, as was the case with indictments before the ICTY. The most complex cases had been those dealt by subsequent WW II military tribunals in respect of civilians, particularly industrial and political leaders. ${ }^{17}$

The ICTR paid particular attention to these distinct anthropological features in its construction of hierarchies and authority in Rwandan society. In the Akayesu case the accused was the burgomaster of Taba commune, a position akin to that of mayor in western parlance. Whereas Western mayors enjoy no other authority than to enact peripheral by-laws and set the municipality's economic agenda on the basis of municipal taxes and other income, in Rwanda the burgomaster enjoyed far greater authority. His powers were found to be much wider than his de jure authority. ${ }^{18}$ In fact, he was perceived as the "father" of the people, whose every order was to be obeyed without question or deviation. ${ }^{19}$ Clearly, informal law and power arrangements, whether explicit or implicit, played an important role in ascertaining the enjoyment of effective control over the actions of civilian populations acting as mobs, random groups or under a self-perceived identity. The existence of such effective control is further reinforced by class and education. This African case study exemplifies the tribunal's desire to construct (or expand) complex liabilities on the basis of anthropological observations in order to reach a just conclusion; in the case at hand to establish the liability of an influential figure urging those under his circle of influence to commit genocide.

\section{The Role and origin of Influence in Sierra Leone's Armed Groups}

The jurisprudence of the SLSC has revealed two broad types of military authority. The first is consistent with that found in regular armies and rebel forces, on the basis of a strict or not so strict hierarchical structure. This seems to be the case with the AFRC and the RUF. The second type of authority depends less on formal hierarchies and is instead entrenched in symbolism and mythology. This much is true with respect to the Komajors and their Civil Defence Forces (CDF). No doubt, elements of both types of authority are found in all groups in one form or another.

That mythology, mysticism and symbolism played a role in the military organisation of Sierra Leone's factions comes as no surprise if one has followed the observations made in earlier sections of this chapter. This was further facilitated by the fact that although the country is host to twenty African groups (the largest of which are the Temne and Mende) it is multi-religious and the war did not start along ethnic or religious lines. Rebel groups and militias were thus ethnically and religiously diverse, a phenomenon already reflected in

\footnotetext{
16 For an excellent anthropological account, see R Lemarchand, Power and Stratification in Rwanda: A Reconsideration (1996) 6 Cahiers d'études Africaines 592.

${ }^{17}$ See Government Commissioner of the General Tribunal of the Military Government for the French Zone of Occupation in Germany v Roechling 14 Trials of War Criminals before the Nuremberg Military Tribunals [Trials] 1097; USA v Flick 6 Trials 1187, and; USA v von Weizsaecker [Ministries case] 14 Trials 308. Once again, although no direct anthropological questions were asked by these tribunals, it was deemed implicit that those to whom powers were delegated by the Nazi regime enjoyed sufficient control over persons committing particular crimes. This was a direct consequence of Nazi culture which permeated all elements of the Reich's socio-economic raison d'etre.

${ }^{18}$ Akayesu Trial judgment, para 57.

${ }^{19}$ Ibid, paras 55,74 .
} 
membership to the country's secret societies, particularly the poro and the bondo. Exceptionally, the composition of the Kamajors was Mende-based, albeit their aim was not necessarily to engage in inter-ethnic rivalries. ${ }^{20}$ That the Special Court made a serious effort to explain the mythology and mysticism underlying the organisation of the Komajors is evidence of the fact that socio-anthropological phenomena are of acute relevance in ascribing the attributes of authority in order to construct complex liabilities. It will be recalled that the ICTY largely rejected or, at least, ignored such factors on the assumption that factions on the territory of Bosnia were neatly divided along ethnic/religious lines and as a result there was no need to enquire in other shared traits between members of the groups.

I will draw on one element here that is intriguing and which although rejected by the ICTY should have found a place in the jurisprudence of the Special Court. I am referring to the power or authority to "influence" as an indication or evidence of effective control. Indeed, in the Celebići case the accused Delalič was found to be a highly influential figure in the Bosniac army. He would possess authority to sign contracts and release orders in a POW camp and liaise with the highest echelons of the Bosnian Muslim authorities; yet, he did not possess formal authority over other subordinates, especially those in the POW camp. The Tribunal did not consider that this highly influential individual, in the absence of any direct subordinates, yielded sufficient control over those running the POW camp such that would have allowed him to intervene in the commission of crimes against the prisoners. ${ }^{21}$ This conclusion was drawn at a time when the construction of the complex liability of command responsibility did not warrant open-ended expansion. It was enough for the Tribunal that only persons exercising effective control over subordinates were subject to the doctrine. It rightly felt that if everyone yielding influence could also be encompassed the floodgates would be open to convict persons that were not at fault. ${ }^{22}$ The key word here is fault. If D, a boy-scout leader, has exerted and continues to exert significant influence over a group of boy scouts who are recruited as minors by a rebel group, it cannot be seriously claimed that he possesses sufficient control over all their future actions, particularly when they are spatially and geographically removed from him. D clearly lacks fault for failing to use his powers of influence to dissuade the youths. However, if D was in proximity to the minors and was an influential figure in the broader echelons of the group, he possesses the material capacity to employ his influence over the minors, even if he does not enjoy effective control by reason of direct subordination. In this latter scenario $\mathrm{D}$ is at material fault, although it will depend on the particular circumstances of each as to whether this fault may substantiate command responsibility. These particular circumstances are none other than D's material capacity to act. ${ }^{23}$ It defies logic and the dictates of justice to assert that a person with the direct capacity to save hundreds of lives by simply averting the would-be perpetrators bears no liability simply because he was not incumbent with a pre-existing duty to act. This is not merely an iteration or transplantation of the duty to save strangers typically associated with civil law jurisdictions. It goes at the very heart of material fault and all that it stands for.

\footnotetext{
${ }^{20}$ K Dupuy, HM Binningsbø, Power-Sharing and Peace-Building in Sierra Leone (CSCW Papers 2007) 3-4.

${ }^{21}$ ICTY Prosecutor v Delalić et al [Čelebići case], Trial Chamber judgment (16 Nov 1998), paras, 266, 653-56.

${ }^{22}$ This is particularly reflected in its pronouncements in ICTY Prosecutor v Brdjanin and Talić (1 Sep 2004), Trial Chamber Judgment, paras 276, 281; ICTY Prosecutor v Naletilić and Martinović, Trial Chamber Judgment (21 Mar 2003), para 68. These judgments certainly influenced the decision of the State Court of Bosnia and Herzegovina in Prosecutor v Alić, Trial Chamber Judgment, Case No X-KR-06/294 (11 Apr 2008) at 46.

${ }^{23}$ This is why Mettraux, above note 3, sides with the judgments of the ICTY to reject influence as establishing de facto control.
} 
It is not clear whether the SLSC shares this conviction given that it has not expressly rejected or upheld this thesis. ${ }^{24}$ It is certain that the Special Court was unaware of the scholarly literature suggesting that power of influence is possible even in the absence of authority over one's target audience. ${ }^{25}$ Imagine if influence and authority are merged into a single entity. Had the Special Court been cognisant of these arguments it might have taken up the proposition that in situations where the power relations and social status between several individuals is chaotic, direct subordination is not necessary in order for the more influential person to establish effective control merely by his or her powers of influence. ${ }^{26}$ This chaotic power gap certainly existed in the context of the military factions engaged in Sierra Leone's bloody wars. The spiritual leader of the Kamajors, Kondewa, is an interesting case study. The Kamajors were originally organised as a group of Mende hunters who responded to the directives of their various chiefs to protect people from the rebels. ${ }^{27}$ As a result, its members did not possess the military skills and discipline of a regular or rebel army. They were in need of organisation and guidance in order to become an organised fighting unit. ${ }^{28}$ This guidance came both from military as well as spiritual leaders. Kondewa was of the latter kind.

He was the head of all the CDF initiators initiating the Kamajors into the Kamajor society in Sierra Leone. His job was to prepare herbs which the Kamajors smeared on their bodies to protect them against bullets. Kondewa was not a fighter, he himself never went to the war front or into active combat, but whenever a Kamajor was going to war, he would go to Kondewa for advice and blessing. (...) The Kamajors believed in the mystical powers of the initiators, especially Kondewa, and that the process of the initiation and immunisation would make them bullet-proof. The Kamajors looked up to Kondewa and admired the man with such powers. (...) Because of the mystical powers Kondewa possessed, he had command over the Kamajors from every part of the country. ${ }^{29}$

The Special Court opined that Kondewa's mystical powers did not automatically confer upon him military authority over the recruits and their operations. ${ }^{30}$ On the contrary, it was his de jure position of High Priest of the CDF that granted him some degree of effective control in certain situations and it was in respect of these that he was found to enjoy effective control. ${ }^{31}$

The Special Court missed a golden opportunity to defy the Čelebici myth by expressly stipulating that under certain circumstances the yielding of influence between asymmetric actors can give rise to effective control irrespective of the military, civilian or other context in which it is exercised. If a person can convince another that following a ritual he will be unaffected by his adversaries' weapons it is absurd to claim that this person does not possess powers akin, if not far superior, to those enjoyed in a superior-subordinate relationship. Such powers of influence are no doubt rare, but in Sierra Leone where the mystical and the symbolic coincide with the real and the brutal the anthropological basis of the relevant

\footnotetext{
${ }^{24}$ In SLSC Prosecutor v. Brima, Kanaru and Kanu, Judgement (20 June 2007), para 788 the Special Court referred to a number of indicia as evidence of effective control. These may implicitly be read - although one could argue otherwise - as encompassing cases of significant and overpowering influence.

25 See LA Hill, Exercising Influence without Formal Authority: How New Managers can Build Power and Influence (Harvard Business Press, 2008); AR Cohen, DL Bradford, Influence without Authority (Wiley, 2005). Hill's motto, a pioneer on this topic, is that: "all influential managers have power but not all powerful managers have influence".

${ }^{26}$ Influence is probably not the appropriate term here and this certainly explains why the ad hoc tribunals have rejected influence-based effective control out-of-hand. It should be understood as possessing the material and mental power to compel another to do or abstain from doing something.

${ }^{27}$ SLSC Prosecutor v. Fofana and Kondewa, Judgment (2 Aug 2007), para 354.

28 Even so, universal discipline remained problematic because some fighters "acted on their own without knowledge of central command because their area of operation was so wide". Id, para 358 .

${ }^{29} \mathrm{Id}$, paras 344-346.

${ }^{30}$ Ibid, para 806.

${ }^{31}$ Ibid, para 686.
} 
relationships should have been given much more prominence. Just like the results of one anthropological study cannot be transplanted into another - although some general observations may be possible - in the same manner the findings of the Special Court need not necessarily have to be accepted as immutable truths applicable in all future conflicts. I am not convinced by the argument that influence can never give rise to effective control-type situations. This position is sustainable of course as long as it is proven that the person in question had the material capacity to prevent or punish the crimes committed by those persons over whom he enjoyed significant influence. I can only hope that the jurisprudence will take anthropological evidence into consideration and finally move towards this direction. 